the most frequent length was eighteen es; the next most frequent twenty-four; the next twenty inches. He referred to cases of Mr. Stone, in which the cord not more than six inches long, and in tich the abdomen had been torn from it. if alluded to a case of a cord which he Iad exhibited to the society, which was Gity-five inches long. With regard to the aitiest period at which the cord was found (be coiled round the neck of the foetus, he Clibited a preparation belonging to $\mathrm{Mr}$. fughes, in which the foetus was about the forth month, and another from the museum ODr. Chowne, in which the foetus was profobly about the eleventh week : in both these cases the cord was coiled round the pek. With respect to the treatment of prohissus of the funis, he referred to the valubble atlas of Moreau, edited by himself, in thich he had given the statistics of thirtyeren thousand four hundred and seventyfour cases; and of these the funis presented 端 one hundred and ninety-nine cases, or about one in two hundred. There were two hinds of funis presentation-the one conisted of those cases in which the funis got fatangled below or beside the head, and had iot passed up; and the other consisted of Hose instances in which the cord had been hbove the head, but was brought down by the fush of water. With regard to the various means which had been adopted for the reduction of the prolapsus, much would depend on the period of the labour at which the prohipsus took place. Where the cord was not impacted, the support of the finger, or of sponge or cotton introduced into the ragina, inght be of service; but these were of no ise when the cord was impacted. $\mathrm{He}$ obJeted to version, as it had proved fatal in the ratio of one in fifteen to the mother; and it was known that every third child died in cases where version was performed for all sorts of purposes. The forceps had been occasionally employed with success. Converging the funis into the sacro-ischiatic notch, might in some cases, where there was room, succeed in preserving the life of the child. Still he objected altogether to instruments, and the cord was often so long as to render it dangerous to attempt to return it. Twisting the cord in various ways might perhaps reduce the prolapsus in the manner in which a hernia was reduced. But cases must be treated according to circumstances : Sir R. Croft, in two cases, had succeeded in hooking the funis over the limbs of the infant.

Dr. REID had never met with a statement respecting the twisting of the cord in prolapsus similar to that mentioned by Mr. Streeter. He had, however, noticed in cases in which the child was hastily born, that the cord was occasionally twisted in that manner. He thought in version that he had felt the same state of the cord in the womb, but it was ge-

nerally flaccid, even when the ehild was alive. The cause of the twisting of the vessels in the cord had been attempted to be explained in various ways; one of the most prevalent opinions was, that the arteries being longer than the veins, it was necessary that they should be coiled, in order to be contained in the same sheath.

Mr. Streeter remarked, that the coiling he mentioned did not cease when the pulsation in the cord ceased, some elasticity being still left in the cord. When the vessels of the cord were first formed they were of uniform length; there must be some specific cause, then, for the coiling of the arteries.

Dr. Chowne said, that there were some circumstances which reudered Mr. Streeter's view of the cause of the infrequent prolapsus of the cord probable. One of these was the fact, that the cord seldom prolapsed until after the death of the child: generally when the funis presented the child was dead. He showed objections to the various modes of treatment which had been recommended for prolapsed cord, and remarked that none of them seemed to answer the purpose in practice.

Mr. Dunn had met with seven cases of presentation of the funis : in all, the children were born dead. He had met with a case of knot in the cord.

\title{
UNIVERSITY COLLEGE MEDICAL SOCIETY.
}

Friday, March 11, 1842.

Mr. Marshall, President. colloid cancer.

Mr. M'Dougall read a paper on colloid cancer. After enumerating the various names given to this disease, and the classifi. cations to which it had been referred, the author proceeded to its anatomical characters, viz., that it consists of masses of cells, filled with an elastic, gelatinous substance, of various shades of colour, very tenacious, and not easily removed by pressure. He then adduced the following case :- $\mathbf{A}$ patient, ætat. 42, was admitted into the Colonial Hospital, Hobart Town (whilst he, Mr. M'Dougall, was house-surgeon to that institution), suffering from an ulcer on the leg. He was of intemperate habits, impaired constitution, and of a sallow complexion. After some months' residence in the hospital the ulcer improved, but the patient's health declined : he became very debilitated, and suffered from frequent desire of making water, and ultimately perished from fever. On a post-mortem examination, a mass of diseased structure occupied the position of the omentum, whose external characters, were a nodulated surface, of various colours, in which yellow predominated, and superficial vascularity. At the lower part of the peritoneal 
cavity was an accumulation of uncoagulable fluid. Within the bladder a fungous growth, similar to that in the omentum; the parietes of the bladder much thickened. A sectional view of the omental diseased structure exhibited throughout a number of cells, circumscribed by fibrous septa, and containing the colloid matter, which, on microscopic examination, was found to consist of globules, containing smaller ones, in which were nuclei ; amongst the globules was found also small acicular crystals. The author believed this morbid growth to have originated underneath the peritoneum, though this membrane could not be traced over the surface of the mass. The author "stated the opinions of pathologists to vary as to the primary seat, \&c. of this disease; Dr. Carswell thinking that it may be deposited on the surface of serous membranes ; Professor Walshe, that this is very rare; Andral, that it is a disease of secretion; whilst Cruveilhier considers it to consist of dilated veins. He considered the presence of blood-vessels in the diseased structure as opposed to Dr. Carswell's view of its originating as a deposit on serous surfaces; for how in such cases is the connection established between the vessels of the normal and abnormal tissues, if the deposit originated in the subserous cellular tissue? the connection was easily accounted for. Heregretted that the subject of the disease in question had not been injected, as most observers had hitherto failed in discovering blood-vessels in this form of morbid growth. He believed the cells might arise in the following manner: in a fluid supplied from the blood cells arise, and enlarge by accumulation of young cells within, in whose interior others are again formed; soon the original cell bursts, splits into fibres, allowing the secondary cells to escape, and constituting the septa. Of the causes of this deposit various views are entertained among pathologists; it probably depends on causes inherent in the constitution, as it is found almost universally to recur in some part or the other when removed from any part by operation. It has been found in the rectum, stomach, mesentery, uterus, cæcum, testicle, and bladder. Its symptoms, unless in superficial parts, are obscure, as is seen in this case, in which its existence, though in important organs, was not discovered until after death. As to treatment, it should be by constitutional means-by such remedies as should tend to improve the general health, and that a change of these was desirable. The early stages afforded the only chance of doing much good.

Mr. Morton wished to know if this disease had been removed by operation; if so, with what result.

Dr. LAN Kester thought that if the existence of crystals had been satisfactorily made out, it was an interesting circumstance, as demonstrating in a low state of vital action the co-operation of chemical and rital pheno mena. No satisfactory treatment was likely to be discovered nitil the development of these growths was better known; and this could only result from a better acquaintance with the development of normal tissues. Ho drew some interesting comparisons between the fungous growths of animals and rege. tables.

Mr. M'Dovgall quoted Professor Walshe on a case of colloid cancer remored by operation, and succeeded by an encephaloid tumour. His impression was, that crystals did exist in the morbid growth of which be had been giving an account.

Dr. M'Grigon considered the knife the only remedy for such morbid growths, and that in the present instance its aid could not have been had except by such an operation as the Cæsarean section.

Dr. Quarn thought the present case an instance of the extent to which disease might proceed without characteristic symptoms during life. Such cases point out the necessity of accurate and careful examination, and of treating with indulgence the practices of others in such circumstances. The origin of such growths was to be traced to the earlier processes of sanguification. The existence of cancerous matter in the blood, as described by Dr. Carswell, proved that these growths were not merely the effect of local action of the blood-vessels. He alluded to some recent views promulgated by Dr. Campbell, on the origin of another heterologous formation, tubercle, which this gentleman considered due to a diminished calibre. of the vessels arresting this matter.

$\mathrm{Mr}$. HARDwick thought salivation likely to be beneficial in such cases, and recited a curious case of very extensive cancerous dis: ease discovered after death, but which during life had evinced no symptoms.

Mr. Fennovlet stated, that crystals were frequently found in preparations preserved in spirit: he thought they consisted of the salts of serum, whose water had been abstracted by the alcohol.

Mr. Matriew and Dr. Quain mentioned cases of cancerous diseases in which mercury had been administered to a considerable extent, not with a good, but rather with a very bad effect.

Mr. Marshall believed that colloid eancer generally affected parts out of the reach of operations for removal; statistic accounts he considered not worthy of dependance upon, as to the result of the removal of cancerous growths. The cases were not usually watched long enough to know the true result of operations, and he adduced cases to prove this statement. He corroborated Mr. Fenhoulet's statement, as to the existence of crystals in preparations preserved in spirit, and considered Mr. F.'s explanation of the fact correct. 